\title{
PENGEMBANGAN INSTRUMEN TES DAN NON TES DALAM RANGKA MENYIAPKAN PENILAIAN AUTENTIK PADA KURIKULUM 2013 DI SMP/MTS MUHAMMADIYAH SE-KABUPATEN BANTUL
}

\author{
Oleh: \\ Hani Irawati, Much. Fuad Saifuddin, Destri Ratna Ma'rifah \\ Universitas Ahmad Dahlan Yogyakarta \\ Email: Hani.irawati86@gmail.com
}

\begin{abstract}
Ringkasan
Kurikulum 2013 juga mengamanatkan penilaian hasil belajar peserta didik harus dilaksanankan secara autentik. Penilaian autentik menuntut guru agar dapat mengamati perkembangan peserta didik pada semua aspek perkembangan. Oleh karena mengikuti perkembangan dunia pendidikan, kemampuan peserta didik yang perlu diketahui oleh pendidik tidak hanya terkait kognitif tetapi juga afektif dan psikomotor. Tujuan kegiatan ini adalah memberikan pelatihan dan pendampingan mengenai penyusunan instrumen penilaian bentuk non tes, dan memberikan pelatihan bagaimana cara menganalisis butir soal dengan menggunakan salah satu program analisis butir soal. Kegiatan ini dilakukan dalam bingkai pelatihan dan pendampingan saat guru mengembangkan instrumen penilaian.
\end{abstract}

Kata kunci : pengembangan instrumen, penilaian autentik, kurikulum 2013.

\begin{abstract}
Curriculum 2013 also mandates the assessment of learners' learning outcomes should be carried out authentically. Authentic assessment requires teachers to be able to observe the progress of learners in all aspects of development. Because following the development of the world of education, the ability of learners who need to be known by educators not only related to cognitive but also affective and psychomotor. The purpose of this activity is to provide training and mentoring on the preparation of non-test form assessment instruments, and to provide training on how to analyze items by using one item analysis program. This activity is carried out in a frame of training and mentoring as teachers develop assessment instruments.
\end{abstract}

Keywords: instrument development, authentic assessment, curriculum 2013.

\section{A. PENDAHULUAN}

Menilai dan mengevaluasi merupakan kewajiban yang harus dilakukan oleh seorang guru untuk mengetahui sejauh mana kompetensi yang telah dikuasai oleh peserta didik setelah melakukan proses pembelajaran. Selain itu, kegiatan penilaian dan evaluasi juga dapat dijadikan sebagai tolok ukur keberhasilan guru dalam menyelenggarakan kegiatan penilaian dan evaluasi pembelajaran perlu untuk memperoleh perhatian dalam perencanaan dan proses pelaksanaannya.

\section{IDENTITAS ARTIKEL PPM}

Sesuai dengan amanat dalam Kurikulum 2013, penilaian yang digunakan adalah penilaian autentik. Secara konseptual penilaian autentik lebih bermakna secara signifikan dibandingkan dengan tes pilihan ganda terstandar sekali pun (Kemendikbud, 2013). 
Penilaian autentik mengandung pengertian bahwa dimana seluruh proses dan hasil belajar harus mampu dinilai secara menyeluruh dan tidak hanya dari segi kognitif saja, tetapi mencangkup aspek afektif dan psikomotorik juga.

Sebagaimana jenis instrumen yang telah banyak digunakan selama ini, instrumen berbentuk tes digunakan untuk mengukur pencapaian kompetensi kognitis peserta didik. Selain instrumen yang dapat untuk mengukur kognitif, terdapat pula instrumen untuk mengukur afektif dan psikomotorik yang dapat disebut sebagai instrumen nontes. Instrumen non tes ini yang masih jarang digunakan oleh guru-guru di sekolah. Penilaian Hasil Belajar oleh Pendidik dilaksanakan dengan menggunakan instrumen penilaian (Permendikbud, 2014).

Selama ini instrumen yang banyak dikembangkan oleh guru adalah instrumen berbentuk tes seperti soal pilihan ganda maupun uraian, tetapi instrumen berbentuk non tes untuk mengukur afektif dan psikomotorik masih sangat jarang dikembangkan. Penilaian yang diharapkan pada kurikulum 2013 merupakan penilaian secara menyeuruh baik kognitif, afektif, maupun psikomotorik, sehingga guru harus mampu mengembangkan instrumen penilaian baik tes maupun non tes.

\section{B. METODE PELAKSANAAN}

Metode yang digunakan dalam pengabdian ini adalah ceramah, diskusi, dan praktik. Metode ceramah digunakan pada saat penyampaian materi pengantar tentang pengukuran, penilaian, evaluasi. Diskusi dilakukan pada setiap sesi setelah pemateri memberikan materi, dan praktik dilakukan pada saat guru-guru menyusun instrumen penilaian baik tes maupun non tes. Metode praktik juga digunakan pada saat guru-guru melakukan analisis butir soal dengan menggunakan program ANATES.

\section{PEMBAHASAN}

Kegiatan pengabdian dilakukan mulai dari persiapan kegiatan, koordinasi dengan ketua Dikdasmen PDM Bantuk dan ketua BKS, serta pelaksanaan pelatihan dan pendampingan. Kegiatan pelatihan dan pendampingan untuk menyusun instrumen penilaian tes dan non tes dilakukan selama tiga hari. Kegiatan diawali pada pukul 07.00 WIB dan berakhir pada pukul $17.00 \mathrm{WIB}$. Pada setiap harinya pelatihan dan pendampingan terbagi menjadi 11 sesi. Durasi yang diperlukan untuk satu kali sesi adalah 45 menit.

Pada pertemuan pertama yaitu tanggal 8 Agustus 2017 materi yang disampaikan adalah pengantar mengenai pengukuran, penilaian, dan evaluasi serta penilaian pada kurikulum 2013. Materi pertama memberikan gambaran kepada guru tentang perlunya pemahaman untuk membedakan pengukuran, penilaian, dan evaluasi serta bagaimana penilaian yang diharapkan pada kurikulum 2013 yang dikenal dengan penilaian autentik. Penilaian autentik akan menilai siswa dalam proses dan hasil belajar, sehingga penilaian yang dilakukan tidak hanya pada ranah kognitif saja, akan tetapi pada ranah afektif dan psikomotorik juga.

Kegiatan kedua dilakukan pada hari Senin 14 Agustus 2017. Untuk kegiatan di hari ini, para guru diminta untuk membawa instrumen penilaian yang pernah dibuat ataupun dimiliki. Berpijak dari sana kegiatan pembuat instrumen dapa mengakomodasi prestasi 
guru sebelumnya dalam membuat instrumen. terkait materi yang disampaikan yaitu tentang jenis-jenis instrumen penilaian dan praktik membuat instrumen penilaian.

Jenis instrumen penilaian yang disampaikan ada dua yaitu instrumen penilaian tes dan instrumen penilaian non tes. Instrumen penilaian tes digunakan untuk mengukur kogniti peserta didik sedangkan instrumen penilaian non tes digunakan untuk mengukur afektif dan psikomotorik peserta didik. Setelah diberikan materi pengantar guru-guru melakukan praktik dengan menyusun instrumen penilaian tes untuk masing-masing mata pelajaran yang diampu, berupa soal pilihan ganda dan soal berbentuk uraian kemudian dibahas secara klasikal.

Instrumen penilaian non tes yang disampaikan yaitu instrumen untuk menilai afektif untuk peserta didik. Ada empat tipe karakteristik afektif yang penting yaitu sikap, minat, konsep diri, dan nilai, akan tetapi dalam pelatihan ini yang disampaikan hanya tentang sikap saja. Peserta pelatihan dibimbing untuk membuat instrumen penilaian sikap dan kemudian dibahas secara klasikal.

Ketiga kegiatan dilakukan pada hari Rabu tanggal 16 Agustus 2017. Materi yang disampaikan pada pertemuan ini adalah tentang analisis butir soal dan praktik menggunakan program ANATES untuk menganalisis soal berbentuk pilihan ganda dan uraian. Analisis butir soal merupakan suatu kegiatan yang dilakukan oleh guru dengan tujuan untuk mengetahui kualitas dari soal yang telah dibuat. Adapun di dalam analisis butir soal dapat diketahui tentang validitas, reliabilitas, daya beda, tingkat kesukaran, dan kualitas pengecoh dari soal yang telah dibuat. Program ini digunakan untuk menganalisis butir soal yang terdapat pada instrumen pengukur kemampuan kognitif dari peserta didik.

Peserta pelatihan diberikan pengantar terlebih dahulu mengenai analisis butir soal kemudian setelah itu menginstal software ANATES dan melakukan praktik untuk menganalisis soal yang telah dibawa oleh masing-masing guru. Setelah melakukan analisis butir soal guru dapat mengetahui soal-soal yang memiliki kualitas baik dan kualitas tidak baik. Adapun soal dengan kualitas yang baik selanjutnya dapat digunakan dan disimpan oleh guru untuk menjadi bank soal.

\section{KESIMPULAN}

Kegiatan pengabdian berupa pelatihan dan pendampingan yang dilakukan dengan guru-guru di SMP/MTs se-Kabupaten Bantul berguna untuk melatih guru mengembangkan instrumen penilaian tes dan non tes. Guru memiliki kemampuan untuk mengembangkan instrumen tes dan non-tes, hanya saja masih cukup sulit dalam pencernaan dan pelaksanaannya. Kegiatan pelatihan dan pendampingan berhasil melatih guru untuk menganalisis butir soal guna penilaian aspek kognitif dari peserta didik menggunakan software yang mudah dioperasikan.

\section{DAFTAR PUSTAKA}

Kemendikbud. 2014. Peraturan Menteri Pendidikan dan Kebudayaan No 104 Tahun 2014 tentang Penilaian Hasil Belajar oleh Pendidik pada Pendidikan Dasar dan Pendidikan Menengah. 
Kemdikbud. 2015. Peraturan Menteri Pendidikan dan Kebudayaan No 53 Tahun 2015 tentang Penilaian Hasil Belajar oleh Pendidik dan Satuan Pendidikan Pada Pendidikan Dasar dan Pendidikan Menengah.

Kemdikbud. 2016. Peraturan Menteri Pendidikan dan Kebudayaan No 23 Tahun 2016 tentang Standar Penilaian. 